\title{
PREREQUISITES FOR UNDERTAKING AND DEVELOPING COOPERATION BY INDUSTRIAL AND CONSTRUCTION COMPANIES
}

\author{
Anna Wasiluk \\ Faculty of Management, Bialystok University of Technology, \\ 2 O. St. Tarasiuka Street, 16-001 Kleosin, Bialystok, Poland \\ E-mail: a.wasiluk@pb.edu.pl
}

\begin{abstract}
The text is devoted to the prerequisites for undertaking cooperation by competitive industrial and construction enterprises in the perspective of formation and development of cluster structures. The research problem was formulated in the form of four key questions concerning both present and future cooperation between competing companies. Quantitative research, conducted in late 2014 and early 2015 covered 381 enterprises, including 305 industrial and 76 construction companies. The conducted analysis showed a large deficit in terms of both the existing cooperation and readiness to strengthen it in the near future. Under such conditions, it is therefore difficult to talk about the real possibilities of creation and development of effective cluster structures.
\end{abstract}

Keywords: cooperation, clusters, cross-border cooperation, cross-border clusters.

JEL Classification: L22; L26.

\section{Introduction}

Readiness to undertake cooperation by companies operating in the same industry is a prerequisite for the creation and development of clusters. These structures are now seen as carriers of innovation and competitive position improvement not only for companies, but also for the entire regions. In the border regions not only the development of structures on a national level is desirable, but also those of cross-border range. The fact that the Podlasie province is located at the area where Poland Lithuania and Belarus meet makes creating such structures particularly important (Wasiluk, Daniluk 2013). However, the most important in clusters is cooperation of entities that on every day basis compete against each other. They must recognize the need to operate in such initiatives. It is easier to solve problems in a group of companies operating in the same industry and the success of a competitor does not necessarily mean losing. It can also mean a win for many companies in the same industry.

In the literature, there are many titles devoted to the reasons for creating clusters and their advantages, while there are no publications regarding identification of the degree of readiness to cooperate by companies competing with each other every day, especially in the regional context. This paper will help to fill the gap.

The main aim of this text was presentation of research results regarding the assessment of prerequisites for undertaking cooperation by competing industrial and construction enterprises in Podlaskie and the prospects for tightening it in the near future.

\section{Literature review}

It seems that cooperation is a concept commonly understood, but there are many interpretations of it in the economic discourse (Wasiluk 2013). This is due, in part, to its different types. The concept of cooperation is often associated with the term "collaboration" (Nowak 2011; Połomska-Jasieniowska 2010), which should be understood as synchronization of individual tasks that form one whole. The concept of collaboration is also associated with the term of cooperation, which in most cases refers to the collaboration between enterprises and usually concerns production of goods or providing services, but may also include other areas of company operations such as: research and development, supply, promotion, accounting, personnel policy and so on.

Many authors draw attention to the links between cooperation and trust stressing that they should not be equated, but treated as related athough different phenomena (Gambetta 1988; Gambetta 2001; Good 1988; Baier 2001). Mutual trust can lead to development of cooperation between the actors. It should be stressed, however, that trust is not necessary for its creation (Gambetta 1988; Coleman 1990; Mayer et al. 1995; Laske, 
Neunteufel 2005). Collaboration in fact may result not only from trust, voluntarism or expectations of better results, but also from obligation and expected sanctions resulting from non-cooperation. On the other hand, not all relationships based on trust will result in undertaking cooperation (Mayer et al. 1995; Kale et al. 2000). However, some researchers have a different opinion stressing that trust is a kind of pledge towards cooperation and make an essential starting point for it (Müller 2009; Lenk 2010).

Various causes affect the process of cooperation between companies (Wasiluk 2013). The authors note in their publications many both advantages of cooperation - such as: combining resources and thus the ability to make larger orders; the possibility of sharing costs related to, for example, research or promotion; the extension of sales markets etc., and disadvantages - for example inability to make their own decisions; loss of independence; no possibility to use independently the jointly developed innovations; sharing not only profits, but also participation in the losses, etc. (Rupprecht-Däullary 1994; Child, Faulkner 1998; Strzyżewska 2011; Wasiluk 2013). There is no doubt, however, that readiness of enterprises to undertake cooperation and openness to it are prerequisites for the emergence and development of clusters. These structures are now seen as important factors of innovation, not only in individual companies but also in the entire regions.

\section{Research methodology}

In view of the above theoretical considerations relevant seemed to the author of this text to examine, first of all, the issue of conditions for undertaking cooperation with the competition by industrial and construction companies in the perspective of opportunities for cluster structures creation (and possibly other networks) in Podlaskie province. Considering the above the research problem was formulated in the form of the following questions:

1) What is the level of cooperation between the industrial and construction companies and the competition?

2) What is the interest of the industrial and construction companies in strengthening cooperation with competitors in the near future?

3) To what extent do the individual factors influence the current level of cooperation between the respondents' companies and competition?
4) To what extent the positive changes in various factors may contribute the improvement of cooperation between the respondents' companies and their competitors in the near future?

5) Is there a significant interdependence between the assessment of the impact of various factors on the existing cooperation and evaluation of improving it in the future?

Presented in this text analysis are based on the results of extensive research (the author of this text is a member of a research team) carried out in the framework of an international research project, conducted in the framework of the agreement between the Polish Academy of Sciences and the National Academy of Sciences of Belarus (in 2014-2016) "Readiness of enterprises to create cross-border networking". Quantitative studies, carried out in late 2014 and early 2015 (the fourth quarter of 2014 and the first quarter of 2015), covered 381 enterprises and included 305 industrial and 76 construction companies, whose headquarters were in the region of Podlaskie province (see Table 1). The survey was addressed to the owners or members of senior management.

Table 1. Characteristics of the studied companies (Source: author)

\begin{tabular}{r|r}
\hline \multicolumn{2}{c}{ Companies } \\
\hline construction & industrial \\
$\mathrm{N} \mathrm{( \% )}$ & $\mathrm{N} \mathrm{( \% )}$ \\
\hline
\end{tabular}

Size of the studied companies (number of employees)

\begin{tabular}{l|l|l}
\hline Up to 9 people & $20(26,32 \%)$ & $65(21,31 \%)$ \\
\hline $10-49$ people & $23(30,26 \%)$ & $123(40,33 \%)$ \\
\hline $50-249$ people & $27(35,53 \%)$ & $83(27,21 \%)$ \\
\hline 250 people and more & $6(7,89 \%)$ & $34(11,15 \%)$ \\
\hline
\end{tabular}

Age of the studied entities (number of years on the market)

\begin{tabular}{l|l|l}
\hline Up to 1 year & $1(1,31 \%)$ & $2(0,66 \%)$ \\
\hline $1-3$ years & $12(15,79 \%)$ & $16(5,24 \%)$ \\
\hline $4-10$ years & $15(19,74 \%)$ & $52(17,05 \%)$ \\
\hline More than 10 years & $48(63,16 \%)$ & $235(77,05 \%)$ \\
\hline
\end{tabular}

Identification of factors affecting the establishment of cooperation was based on the analysis of literature (Strzyżewska 2011; Górzyński 2006; Czakon 2007; Bengtsson, Kock 2014; Romanowska 1997; Ford, Håkansson 2013; Skalik 2002; Daszkiewicz 2007) and it also resulted from discussions with experts representing both academia 
and business. Finally, the respondents' assessments concerned 14 areas of undertaking cooperation:

1) Extending the sales market.

2) Joint advertising activities/product promotion.

3) Subcontracting.

4) Operation cost reduction (coordination of purchases, joint transport, storage).

5) Rise of innovation potential (faster generating and implementing product and technology innovations).

6) Products/services quality improvement.

7) Access to the competitor's resources (personnel, technology, machines, equipment etc.).

8) Possibility of realization of bigger contracts/projects.

9) Possibility of participation in tenders/ projects.

10) Possibility of implementation of joint investment projects (ex. joint purchase of expensive technologies, equipment, etc.).

11) Possibilities of implementation joint research and development activities.

12) Access to financial institutions, support programs.

13) Influencing the national and local authorities.

14) Experience from previous cooperation.

The respondents assessed the phenomenon in a seven-point scale, where 1 meant a complete lack of impact and $7-$ a very big impact.

The following statistical measures were used to interpret the results of the research: measures of central tendency - dominant, mean, median and measure of dispersion - the coefficient of variation. The Spearman rank correlation was used to indicate the strength of interdependence between the assessments and with t-Student test its significance was examined. To identify statistically significant differences between assessments of companies the Mann-Whitney test was used.

Statistical calculations were made with the use of STATISTICA Version 12.5.

\section{Analysis of the results and discussion about them}

Respondents assessed low the level of existing cooperation of their companies with competitive entities (see Table 2). This cooperation is slightly higher in the case of industrial enterprises, where both the dominant and the median ranked at 3 . This situation may be a little surprising because in the case of construction business it is often required to establish cooperation with competitors, entering in consortia with them for the purpose of investment realization. This is often the only opportunity to win a tender or receive an order for a project. It can therefore be assumed that lack of ability to cooperate with other construction companies limits their opportunities for development and use of emerging opportunities.

Table 2. Current and future cooperation with competitors in the respondents' opinion (Source: author)

\begin{tabular}{l|c|c|c|c|c}
\hline \multicolumn{1}{c|}{ Companies } & $\bar{x}$ & $M_{e}$ & $D$ & $n_{D}$ & $V$ \\
\hline \multicolumn{7}{c}{ Declared level of cooperation with competitors } \\
\hline construction & 2,67 & 2,00 & 2 & 26 & 47,11 \\
\hline industrial & 2,83 & 3,00 & 3 & 72 & 52,91 \\
\hline \multicolumn{6}{c}{ Degree of interest in strengthening cooperation } \\
in the next 2-3 years \\
\hline construction & 2,89 & 3,00 & 2 & 22 & 49,04 \\
\hline industrial & 3,04 & 3,00 & 3 & 75 & 50,48 \\
\hline \multicolumn{6}{c}{ Correlations of Spearman's ranks } \\
for evaluation of the current level of cooperation \\
and possibilities of its strengthening in the future \\
\hline
\end{tabular}

In case of both groups of the surveyed companies poor differentiation of the respondents' assessments can be observed, although in the case of industrial companies it is slightly higher. Weak optimism can also be seen in assessments of the degree of the studied companies' interest in cooperation with competitors in the near future. It is only slightly different from the current state. This situation is explained by the fact that for decades political, social and economic conditions were unfavorable for collaboration and cooperation in any area of the public sphere, and the dominant attitude - natural in the reality ruled by repressive apparatus of power - was great precaution, egoism and low confidence in contacts with others (Wasiluk 2013).

Conducted Spearman's rank correlation indicates a high dependency between the assessment of current cooperation and the possibility of strengthening it in the near future. The higher the surveyed companies rated their current level of cooperation with the competition the higher level of readiness to strengthen it in the future they presented in their declarations. Taking into account the earlier analyzes of the discussed issues, conducted by the author of this text in frames of other projects (Wasiluk, Daniluk 2013), it appears that companies in 
Podlaskie focus on immediate actions that allow for survival and achievement of even a slight increase. They still see competition as a necessary evil, which in principle they should fight against or in the best simply avoid,

From the perspective of formation and development of cluster links the results are not optimistic. It should be noted that attempts to create and develop clusters have been made in Podlaskie for several years. They were fostered by various kinds of programs, including the Regional Programme for the Development of the Podlasie Region for 2007-2013, which allowed raising funds for initiation of these structures. This was an incentive fo consulting companies and other entities to apply for funds to establish clusters. What was going to happen to these structures after termination of the projects was of a little importance. When applying for funds under these programs, companies belonging to clusters received additional points, which guaranteed them getting financial support for investments. This was an incentive for these companies to join the created structures. No possibility of obtaining further funds often put the end to the duration of such an alliance. In addition, the effects of cluster can often be seen only after a decade. However, it seems that most businessmen in Podlasie, but not only, are focused on the immediate benefits, here and now. Therefore, the important factor, and it is not small, for the development of clusters is certainly the willingness of enterprises to cooperate, including cooperation with competitors. The analysis of the above data leads to the conclusion that many attempts to create clusters in Podlaskie province in the last decade have not been reflected in the improvement of cooperation between enterprises and their readiness to strengthen it in the future.

What caused that companies were undertaking cooperation with the competition? In case of construction companies they were mainly the possibilities to get larger orders, participate in tenders and execute orders as subcontractors (see Fig. 1 and Table 3). Therefore, it can be concluded that cooperation was arising from the specific nature of the construction market, where the realization of projects usually exceeds possibilities of individual companies, and decisions on the selection of contractor are made in tender process. For industrial enterprises the most important reasons to start cooperation, as well as for construction companies, were the possibilities to get larger orders and the expansion of sales market. High impact on cooperation with the competition has also, in this group of companies, their previous experience of such co- operation. Lower evaluation of the impact of past experience on the intensity of cooperation between construction companies is the result of the fact that, as mentioned above (see Table 2) the majority of respondents in this group of companies rated its current level as very low.

The least frequent reasons for undertaking cooperation, in both groups of construction and industrial companies, were promotional activities. Cooperation was also only occasionally undertaken for implementation of joint research and development projects. The rarest reason for undertaking cooperation, both in the group of construction and industrial companies, was joint promotional activities.

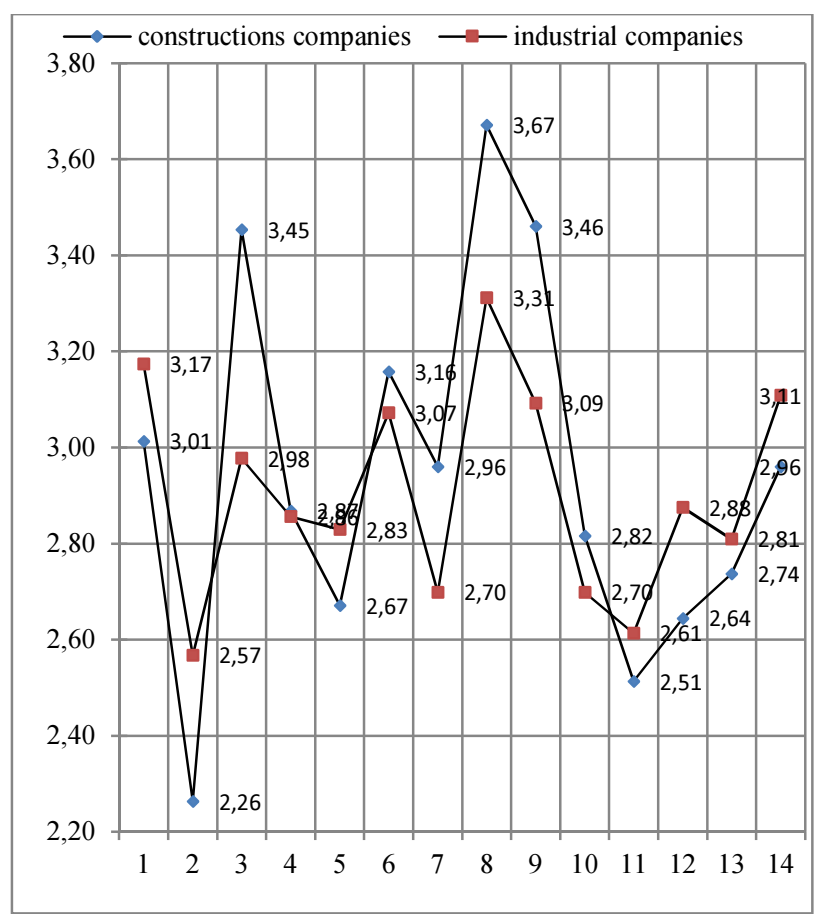

1. extending the sales market;

2. joint advertising activities / product promotion;

3. subcontracting;

4. operation cost reduction (coordination of purchases, joint transport, storage);

5. rise of innovation potential (faster generating and implementing product and technology innovations);

6. products/services quality improvement;

7. access to the competitor's resources (personnel, technology, machines, equipment etc.);

8. possibility of realization of bigger contracts/projects; 9. possibility of participation in tenders/projects;

10. possibility of implementation of joint investment projects (ex. joint purchase of expensive technologies, equipment, etc.);

11. possibilities of implementation joint research and development activities;

12. access to financial institutions, support programs;

13. influencing the national and local authorities;

14. experience from previous cooperation.

Fig. 1. Average rating of the impact of various factors on the level of existing cooperation

(Source: author) 
Table 3. Descriptive statistics for the assessment of the impact of various factors on the level of existing cooperation (Source: author)

\begin{tabular}{|c|c|c|c|c|}
\hline & $M_{e}$ & $D$ & $n_{D}$ & $V$ \\
\hline & \multicolumn{4}{|c|}{$\begin{array}{r}\text { Constructions companies } \\
\text { Industrial companies }\end{array}$} \\
\hline \multirow[t]{2}{*}{ Extending the sales market } & 4,00 & 4 & 16 & 45,94 \\
\hline & 4,00 & 3 & 58 & 44,47 \\
\hline \multirow{2}{*}{$\begin{array}{l}\text { Joint advertising activities / } \\
\text { product promotion }\end{array}$} & 2,00 & 11 & 27 & 66,83 \\
\hline & 3,00 & 1 & 81 & 59,70 \\
\hline \multirow[t]{2}{*}{ Subcontracting } & 4,50 & 5 & 18 & 42,01 \\
\hline & 4,00 & 1 & 64 & 51,47 \\
\hline \multirow{2}{*}{$\begin{array}{l}\text { Operation cost reduction (co- } \\
\text { ordination of purchases, joint } \\
\text { transport, storage) }\end{array}$} & 3,00 & 1 & 22 & 59,11 \\
\hline & 3,00 & 1 & 88 & 60,65 \\
\hline \multirow{2}{*}{$\begin{array}{l}\text { Rise of innovation potential } \\
\text { (faster generating and imple- } \\
\text { menting product and technolo- } \\
\text { gy innovations) }\end{array}$} & 3.00 & 1 & 18 & 56,21 \\
\hline & 3,00 & 4 & 64 & 51,29 \\
\hline \multirow{2}{*}{$\begin{array}{l}\text { Products/services quality im- } \\
\text { provement }\end{array}$} & 4,00 & 1 & 15 & 53,82 \\
\hline & 4,00 & 5 & 59 & 47,51 \\
\hline \multirow{2}{*}{$\begin{array}{l}\text { Access to the competitor's } \\
\text { resources (personnel, technol- } \\
\text { ogy, machines, equipment etc.) }\end{array}$} & 3,00 & 1 & 17 & 54,04 \\
\hline & 3,00 & 1 & 85 & 56,64 \\
\hline \multirow{2}{*}{$\begin{array}{l}\text { Possibility of realization of } \\
\text { bigger contracts/projects }\end{array}$} & 5,00 & 7 & 15 & 42,49 \\
\hline & 4,00 & 5 & 64 & 45,73 \\
\hline \multirow{2}{*}{$\begin{array}{l}\text { Possibility of participation in } \\
\text { tenders/projects }\end{array}$} & 4,00 & 1 & 15 & 52,73 \\
\hline & 4,00 & 1 & 64 & 52,59 \\
\hline \multirow{3}{*}{$\begin{array}{l}\text { Possibility of implementation } \\
\text { of joint investment projects } \\
\text { (ex. joint purchase of expen- } \\
\text { sive technologies, equipment, } \\
\text { etc.) }\end{array}$} & & & & \\
\hline & 3,00 & 1 & 25 & 60,03 \\
\hline & 3,00 & 1 & 112 & 65,02 \\
\hline \multirow{2}{*}{$\begin{array}{l}\text { Possibilities of implementation } \\
\text { joint research and develop- } \\
\text { ment activities }\end{array}$} & 3,00 & 1 & 24 & 59,14 \\
\hline & 2,00 & 1 & 100 & 61,48 \\
\hline \multirow{2}{*}{$\begin{array}{l}\text { Access to financial institu- } \\
\text { tions, support programs }\end{array}$} & 3,00 & 1 & 20 & 56,47 \\
\hline & 3,00 & 1 & 79 & 58,45 \\
\hline \multirow{2}{*}{$\begin{array}{l}\text { Influencing the national and } \\
\text { local authorities }\end{array}$} & 3,00 & 1 & 22 & 59,26 \\
\hline & 3,00 & 1 & 85 & 58,41 \\
\hline \multirow{2}{*}{$\begin{array}{l}\text { Experience from previous co- } \\
\text { operation }\end{array}$} & 4,00 & 3 & 18 & 41,82 \\
\hline & 4,00 & 4 & 64 & 44,88 \\
\hline
\end{tabular}

These results fit into the image of Polish enterprises presented in numerous analysis of innovativeness (Ministerstwo Rozwoju Regionalnego 2006; Ministerstwo Nauki i Szkolnictwa Wyższego 2006; Baczko 2012; Polska Agencja Rozwoju Przedsiębiorczości 2015). They show that Polish companies very rarely undertake carrying out research and development activities. Expenditures on innovation activities in enterprises are intended mostly for the purchase of machinery and equipment, while to conduct research and development only $13.3 \%$ of resources is spent in industrial enterprises and $13.6 \%$ in the service sector (Bromski 2013). Although the analysis of Eurostat data shows that in 2010-2012 in most EU countries entrepreneurs limited their spending on innovation, in view of the fact that Poland had the second place in the rankings of innovativeness in the Community (Eurostat Statistics Explained 2016), it is not optimistic that in the same period in Poland the percentage of innovative companies fell from $28 \%$ in $2009-2011$ to $23 \%$ in the analyzed period (Polska Agencja Rozwoju Przedsiębiorczości 2015). In case of the surveyed construction companies the incentive to cooperation was also the possibility of access to financial institutions and support programs, the activities of which were aimed at supporting projects that required cooperation between companies. Whereas in case of industrial companies it was the opportunity to implement joint investment projects and access to the resources of a competitor.

Interesting seemed to examine whether the positive changes in the identified areas of cooperation will influence its improvement in the near future (see Fig. 2 and Table 4).

In the opinion of respondents from the construction sector the positive changes in feasibility of larger orders (projects), subcontracted works and opportunities to participate in tenders have the greatest impact on improving cooperation of their businesses with the competition. Whereas a little effect will have: changes in the area of joint advertising activities and impact on the national and local authorities. The respondents in this group of companies did not also assume that the actions taken by them in order to increase the innovation potential would encourage their companies to cooperate with other construction companies.

Industrial companies indicated mostly the positive changes in terms of the possibility of getting orders, efforts to expand the sales market or actions to reduce operating costs and improve product quality as factors affecting the improvement of cooperation in the future. Unfortunately, little impact on improving cooperation was perceived in growth of the ability to carry out joint research and development projects, implementation of joint investment projects and influence on the national and local authorities. 


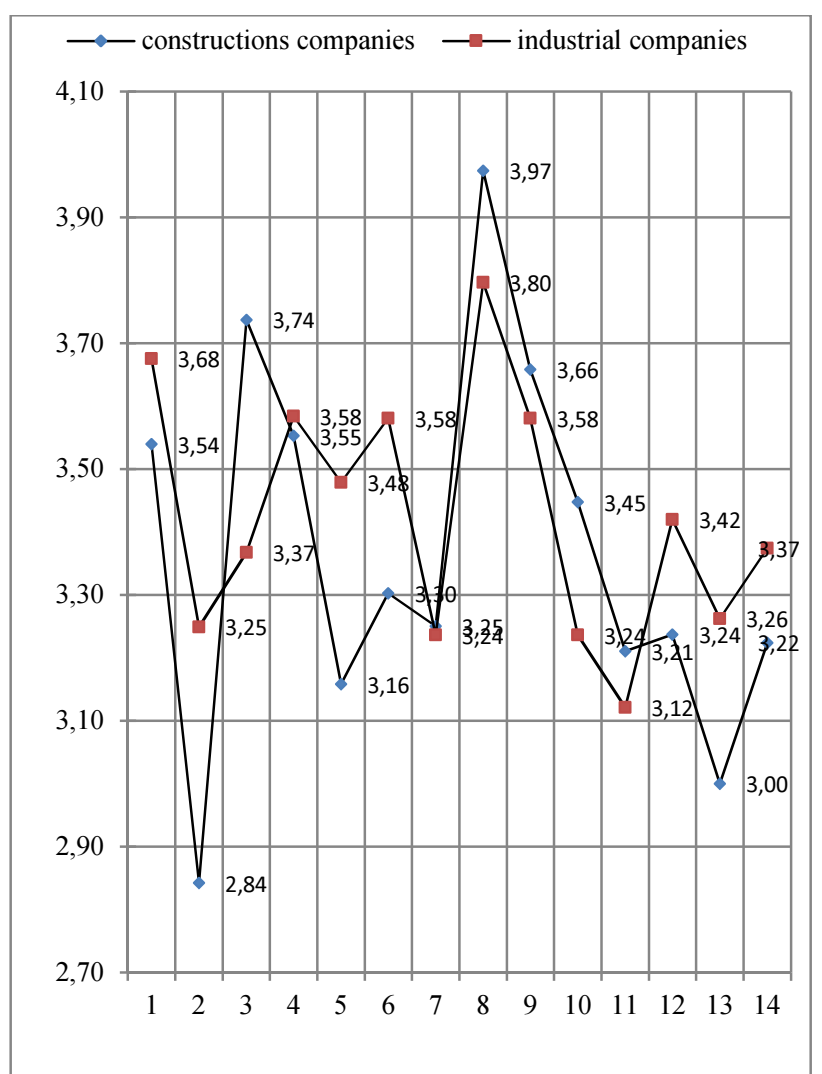

1. extending the sales market;

2. joint advertising activities / product promotion;

3. subcontracting;

4. operation cost reduction (coordination of purchases, joint transport, storage);

5. rise of innovation potential (faster generating and implementing product and technology innovations);

6. products/services quality improvement;

7. access to the competitor's resources (personnel, technology, machines, equipment etc.);

8. possibility of realization of bigger contracts/projects; 9. possibility of participation in tenders/projects;

10. possibility of implementation of joint investment projects (ex. joint purchase of expensive technologies, equipment, etc.);

11. possibilities of implementation joint research and development activities;

12. access to financial institutions, support programs;

13. influencing the national and local authorities;

14. experience from previous cooperation.

Fig. 2. Average rating of the impact of positive changes in various factors on the degree of strengthening cooperation in the near future (2-3 years) (Source: author)

The use of U Mann-Whitney test leads to the conclusion that statistically significant differences in the assessment of the impact of various factors on the level of existing cooperation with competitors are present only in the area of subcontracting. Its impact is assessed higher by construction companies than by industrial companies. In assessments of the impact of other factors, on both the current and future cooperation, no statistically significant differences were found (see Table 5).
Table 4. Descriptive statistics for the assessment of the impact of positive changes in various factors on the level of cooperation in the near future (Source: author)

\begin{tabular}{|c|c|c|c|c|}
\hline & $M_{e}$ & $D$ & $n_{D}$ & $V$ \\
\hline & \multicolumn{4}{|c|}{$\begin{array}{r}\text { Constructions companies } \\
\text { Industrial companies }\end{array}$} \\
\hline \multirow[t]{2}{*}{ Extending the sales market } & 4,00 & 4 & 17 & 54,48 \\
\hline & 4,00 & 1 & 56 & 53,26 \\
\hline \multirow{2}{*}{$\begin{array}{l}\text { Joint advertising activities / } \\
\text { product promotion }\end{array}$} & 3,00 & 1 & 28 & 60,28 \\
\hline & 3,00 & 1 & 68 & 53,46 \\
\hline \multirow[t]{2}{*}{ Subcontracting } & 4,00 & 4 & 20 & 46,53 \\
\hline & 3,00 & 1 & 66 & 53,18 \\
\hline \multirow{2}{*}{$\begin{array}{l}\text { Operation cost reduction (co- } \\
\text { ordination of purchases, joint } \\
\text { transport, storage) }\end{array}$} & 4,00 & 4 & 18 & 52,89 \\
\hline & 4,00 & 1 & 62 & 51,07 \\
\hline \multirow{2}{*}{$\begin{array}{l}\text { Rise of innovation potential } \\
\text { (faster generating and imple- } \\
\text { menting product and technolo- } \\
\text { gy innovations) }\end{array}$} & 3,00 & 4 & 19 & 53,50 \\
\hline & 4,00 & 4 & 69 & 52,40 \\
\hline \multirow{2}{*}{$\begin{array}{l}\text { Products/services quality im- } \\
\text { provement }\end{array}$} & 3,00 & 1 & 19 & 58,72 \\
\hline & 4,00 & 1 & 61 & 52,06 \\
\hline \multirow{2}{*}{$\begin{array}{l}\text { Access to the competitor's } \\
\text { resources (personnel, technol- } \\
\text { ogy, machines, equipment etc.) }\end{array}$} & 3,00 & 1 & 17 & 55,53 \\
\hline & 3,00 & 1 & 78 & 56,24 \\
\hline \multirow{2}{*}{$\begin{array}{l}\text { Possibility of realization of } \\
\text { bigger contracts/projects }\end{array}$} & 4,00 & 4 & 17 & 46,12 \\
\hline & 4,00 & 5 & 64 & 48,51 \\
\hline \multirow{2}{*}{$\begin{array}{l}\text { Possibility of participation in } \\
\text { tenders/projects }\end{array}$} & 4,00 & 5 & 17 & 50,42 \\
\hline & 4,00 & 1 & 61 & 51,47 \\
\hline \multirow{2}{*}{$\begin{array}{l}\text { Possibility of implementation } \\
\text { of joint investment projects } \\
\text { (ex. joint purchase of expen- } \\
\text { sive technologies, equipment, } \\
\text { etc.) }\end{array}$} & 3,00 & $1 / 3$ & 17 & 55,12 \\
\hline & 3,00 & 1 & 80 & 56,19 \\
\hline \multirow{2}{*}{$\begin{array}{l}\text { Possibilities of implementation } \\
\text { joint research and develop- } \\
\text { ment activities }\end{array}$} & 3,00 & 1 & 20 & 56,02 \\
\hline & 3,00 & 1 & 79 & 56,35 \\
\hline \multirow{2}{*}{$\begin{array}{l}\text { Access to financial institu- } \\
\text { tions, support programs }\end{array}$} & 3,00 & 1 & 20 & 56,60 \\
\hline & 3,00 & 1 & 70 & 54,35 \\
\hline \multirow{2}{*}{$\begin{array}{l}\text { Influencing the national and } \\
\text { local authorities }\end{array}$} & 2,50 & 1 & 20 & 61,34 \\
\hline & 3,00 & 1 & 76 & 56,01 \\
\hline \multirow{2}{*}{$\begin{array}{l}\text { Experience from previous co- } \\
\text { operation }\end{array}$} & 3,00 & 1 & 18 & 57,22 \\
\hline & 3,00 & 1 & 69 & 54,33 \\
\hline
\end{tabular}


Table 5. Test $U$ Mann-Whitney test to assess the impact of various factors on the current and future cooperation (Source: author)

\begin{tabular}{|c|c|c|c|c|}
\hline \multirow{4}{*}{ Factors } & \multicolumn{4}{|c|}{$U$ Mann-Whitney Test } \\
\hline & \multicolumn{4}{|c|}{ Cooperaton } \\
\hline & \multicolumn{2}{|c|}{ current } & \multicolumn{2}{|c|}{ future } \\
\hline & $\mathrm{z}$ & $\mathrm{p}$ & $\mathrm{z}$ & $\mathrm{P}$ \\
\hline Extending the sales market & $-0,58$ & 0,56 & $-0,51$ & 0,61 \\
\hline $\begin{array}{l}\text { Joint advertising activities / } \\
\text { product promotion }\end{array}$ & $-1,15$ & 0,25 & $-1,84$ & 0,07 \\
\hline Subcontracting & $\underline{2,00}$ & $\underline{0,05}$ & 1,66 & 0,10 \\
\hline $\begin{array}{l}\text { Operation cost reduction } \\
\text { (coordination of purchases, } \\
\text { joint transport, storage) }\end{array}$ & $-0,08$ & 0,94 & $-0,20$ & 0,84 \\
\hline $\begin{array}{l}\text { Rise of innovation poten- } \\
\text { tial (faster generating and } \\
\text { implementing product and } \\
\text { technology innovations) }\end{array}$ & $-0,77$ & 0,44 & $-1,34$ & 0,18 \\
\hline $\begin{array}{l}\text { Products/services quality } \\
\text { improvement }\end{array}$ & 0,01 & 0,99 & $-1,21$ & 0,23 \\
\hline $\begin{array}{l}\text { Access to the competitor's } \\
\text { resources (personnel, tech- } \\
\text { nology, machines, equip- } \\
\text { ment etc.) }\end{array}$ & 1,00 & 0,32 & 0,09 & 0,93 \\
\hline $\begin{array}{l}\text { Possibility of realization of } \\
\text { bigger contracts/projects }\end{array}$ & 1,33 & 0,18 & 0,75 & 0,45 \\
\hline $\begin{array}{l}\text { Possibility of participation } \\
\text { in tenders/projects }\end{array}$ & 1,41 & 0,16 & 0,36 & 0,72 \\
\hline $\begin{array}{l}\text { Possibility of implementa- } \\
\text { tion of joint investment } \\
\text { projects (ex. joint purchase } \\
\text { of expensive technologies, } \\
\text { equipment, etc.) }\end{array}$ & 0,70 & 0,48 & 0,78 & 0,44 \\
\hline $\begin{array}{l}\text { Possibilities of implemen- } \\
\text { tation joint research and } \\
\text { development activities }\end{array}$ & $-0,41$ & 0,68 & 0,35 & 0,73 \\
\hline $\begin{array}{l}\text { Access to financial institu- } \\
\text { tions, support programs }\end{array}$ & $-0,61$ & 0,54 & $-0,73$ & 0,47 \\
\hline $\begin{array}{l}\text { Influencing the national } \\
\text { and local authorities }\end{array}$ & $-0,12$ & 0,90 & $-1,16$ & 0,25 \\
\hline $\begin{array}{l}\text { Experience from previous } \\
\text { cooperation }\end{array}$ & $-0,57$ & 0,57 & $-0,68$ & 0,49 \\
\hline
\end{tabular}

$\mathrm{P}<0,05$

There is a high positive correlation between the assessment of the impact of various factors on the existing cooperation and evaluation of the possibility for improving it in the future, in both construction and industrial companies (see Table 6). Spearman's rank correlation conducted for the respondents' assessments leads to the conclusion that
Table 6. Spearman's rank correlations for the impact of various factors on the existing level of cooperation and the possibility for improving it in the future resulting from positive changes in the factors (Source: author)

\begin{tabular}{|c|c|c|}
\hline \multicolumn{3}{|c|}{ Correlations of Spearman's ranks } \\
\hline \multirow[b]{2}{*}{ Factors } & \multicolumn{2}{|c|}{ Companies } \\
\hline & $\begin{array}{l}\text { construc- } \\
\text { tion }\end{array}$ & industrial \\
\hline Extending the sales market & 0,7240 & 0,6645 \\
\hline $\begin{array}{l}\text { Joint advertising activities / } \\
\text { product promotion }\end{array}$ & 0,7540 & 0,6434 \\
\hline Subcontracting & 0,6993 & 0,6456 \\
\hline $\begin{array}{l}\text { Operation cost reduction (co- } \\
\text { ordination of purchases, joint } \\
\text { transport, storage) }\end{array}$ & 0,6597 & 0,6487 \\
\hline $\begin{array}{l}\text { Rise of innovation potential } \\
\text { (faster generating and imple- } \\
\text { menting product and technolo- } \\
\text { gy innovations) }\end{array}$ & 0,6155 & 0,6570 \\
\hline $\begin{array}{l}\text { Products/services quality im- } \\
\text { provement }\end{array}$ & 0,7260 & 0,6450 \\
\hline $\begin{array}{l}\text { Access to the competitor's } \\
\text { resources (personnel, technol- } \\
\text { ogy, machines, equipment etc.) }\end{array}$ & 0,6485 & 0,6937 \\
\hline $\begin{array}{l}\text { Possibility of realization of } \\
\text { bigger contracts/projects }\end{array}$ & 0,7560 & 0,6291 \\
\hline $\begin{array}{l}\text { Possibility of participation in } \\
\text { tenders/projects }\end{array}$ & 0,7066 & 0,6769 \\
\hline $\begin{array}{l}\text { Possibility of implementation } \\
\text { of joint investment projects } \\
\text { (ex. joint purchase of expen- } \\
\text { sive technologies, equipment, } \\
\text { etc.) }\end{array}$ & 0,6088 & 0,6312 \\
\hline $\begin{array}{l}\text { Possibilities of implementation } \\
\text { joint research and develop- } \\
\text { ment activities }\end{array}$ & 0,7128 & 0,6228 \\
\hline $\begin{array}{l}\text { Access to financial institu- } \\
\text { tions, support programs }\end{array}$ & 0,7210 & 0,6285 \\
\hline $\begin{array}{l}\text { Influencing the national and } \\
\text { local authorities }\end{array}$ & 0,7734 & 0,6763 \\
\hline $\begin{array}{l}\text { Experience from previous co- } \\
\text { operation }\end{array}$ & 0,7086 & 0,7343 \\
\hline
\end{tabular}

$\mathrm{P}<0,05$

the increase in the level of evaluation of the individual factors' impact on the current level of cooperation is accompanied by an increase in the average value of the evaluation level of the impact of positive changes in these factors on establishment of cooperation in the future. 


\section{Conclusions}

The carried out analyzes show a large deficit in terms of both the existing cooperation and readiness to strengthen it in the near future. Although the analysis pointed to areas in which cooperation is taken most often and where the positive changes have impact on strengthening cooperation in the future, it should be noted that the strength of these factors influence did not exceed level 4 at the 7-level rating scale. Therefore, their power to affect the readiness of companies to cooperate should be assessed as rather weak. Consideration should be given on measures that would help to improve this state. However, it is difficult to say that this was possible in a short period of time. It is rather a task for years. It may require bringing up a new generation of entrepreneurs who will not be afraid of cooperation, but will see the road to success in it.

Lack of readiness to cooperate by companies in Podlasie, and not only, is not limited to the competition. Analyses carried out by the author of this text for different publications indicate a large deficit in this respect also, among others, in relation to the institutions of science and local government (Wasiluk 2015). In such conditions it is difficult to talk about the real possibilities for creation and development of effective cluster structures.

\section{References}

Baczko, T. 2012. Raport o innowacyjności gospodarki Polski w 2012 roku. Warszawa: Instytut Nauk Ekonomicznych PAN.

Baier, A. 2001. Vertraue und seine Grenzen in M. Hartmann, C. Offe (Eds.). Vertrauen. Die Grundlage des sozialen Zusammenhalts. Frankfurt - New York: Campus.

Bengtsson, M.; Kock S. 2014. Coopetition - Quo Vadis? Past accomplishments and future challenges, Industrial Marketing Management 43(2): 180-188.

Bromski, K. 2013. Wspólpraca nauki i biznesu. Doświadczenia i dobre praktyki wybranych projektów w ramach Programu Operacyjnego Innowacyjna Gospodarka na lata 2007-2013. Warszawa: PARP.

Child, J.; Faulkner, D. 1998. Strategies of co-operation. managing alliances, networks and joint ventures. Oxford: Oxford University Press.

Coleman, J. S. 1990. Fundations of social theory. Cambridge - Massachusetts - London: the Belknap Press of Harvard University Press.
Czakon, W. 2007. Dynamika więzi międzyorganizacyjnych przedsiębiorstwa. Katowice: Wydawnictwo Akademii Ekonomicznej w Katowicach.

Daszkiewicz, N. 2007. Małe i średnie przedsiębiorstwa. Szanse i zagrożenia rozwoju. Warszawa: CeDeWu.

Eurostat Statistics Explained. 2016. Innovationsstatistik [online], [cited 16 January 2016]. Available from Internet: http://ec.europa.eu/eurostat/statisticsexplained/index.php/Innovation_statistics/de

Ford, D.; Håkansson, H. 2013. Competition in business networks, Industrial Marketing Management 42: 1017-1024. http://dx.doi.org/10.1016/j.indmarman.2013.07.015

Gambetta, D. 1988. Can we trust? Making and breaking cooperative relation. Oxford - Cambridge: Basil Blackwell.

Gambetta, D. 2001. Können Wir dem Vertrauen Vertrauen? Vertrauen. Die Grundlage des sozialen Zusammenhalts. Frankfurt - New York: Campus.

Good, D. 1988. Individuals, interpersonal relations, and trust in Gambetta. Making and breaking cooperative relation. Oxford - Cambridge: Basil Blackwell.

Górzyński, M. 2006. System wspierania gron przedsiębiorczości. Publikacja podsumowująca. Rzeszów: IG WSIiZ.

Kale, P.; Singh, H.; Perlmutter, H. 2000. Learning and protection of properietary assets in strategic alliances: building relational capital, Strategic Management Journal 21(3): 217-237.

http://dx.doi.org/10.1002/(sici)1097-0266

(200003)21:3<217::aid-smj95>3.0.co;2-y

Laske, M.; Neunteufel, H. 2005. Vertrauen eine "Conditio sine qua non" für Kooperationen? Wismarer Diskussionspapiere 01.

Lenk, H. 2010. Vertrauen als Relationales Interpretations - und Emotionskonstrukt in Maring. Vertrauen - Zwischen Sozialem Kitt und der Senkung von Transaktionskosten. Karlsruhe: KIT Scientific Publishing.

Mayer, R. C.; Davis, J. H.; Schoorman, F. D. 1995. An integrative model of organizational trust, Academy of Management Review 20(3): 709-734. http://dx.doi.org/10.2307/258792

Ministerstwo Nauki i Szkolnictwa Wyższego. 2006. Bariery wspótpracy przedsiębiorców i ośrodków naukowych. Raport. Departament Wdrożeń i Innowacji, Warszawa.

Ministerstwo Rozwoju Regionalnego. 2006. Program Operacyjny Innowacyjna Gospodarka 2007-2013. Warszawa.

Müller, J. H. 2009. Vertrauen und Kreativität. Zur Bedeutung von Vertrauen für Diversive AkteurInnen. Frankfurt: Peter Lang.

Nowak, D. 2011. Powiqzania kooperacyjne - wstępna charakterystyka relacji in Stępień. Międzynarodowa kooperacja gospodarcza z polskiej perspektywy. Warszawa: PWE. 
Polska Agencja Rozwoju Przedsiębiorczości. 2015. Innowacyjna przedsiębiorczość w Polsce. Odkryty $i$ ukryty potencjat polskiej innowacyjności. Raport. Warszawa.

Połomska-Jasieniowska, A. 2010. Wewnętrzne uwarunkowania współdziałania gospodarczego matych przedsiębiorstw. Wyzwania i perspektywy zarzadzania $w$ matych $i$ średnich przedsiębiorstwach. Warszawa: C.H. Beck.

Romanowska, M. 1997. Alianse strategiczne przedsiębiorstw. Warszawa: PWE.

Rupprecht-Däullary, M. 1994. Zwischenbetriebliche Kooperation. Wiesbaden: Springer. http://dx.doi.org/10.1007/978-3-663-01291-7

Skalik, J. 2002. Zmiana warunkiem sukcesu. Integracja, globalizacja, regionalizacja - wyzwania dla przedsiębiorstw. Wrocław: Wydawnictwo Akademii Ekonomicznej we Wrocławiu.
Strzyżewska, M. 2011. Wspótpraca między przedsiębiorstwami. Odniesienie do polskiej praktyki. Warszawa: Oficyna Wydawnicza SGH.

Wasiluk, A. 2015. Zaufanie a współpraca pomiędzy podmiotami gospodarczymi a instytucjami samorządowymi, in Ogólnopolska konferencja naukowa "Doskonalenie systemów zarzqdzania w instytucjach publicznych - efektywność i skuteczność realizowanych działań $w$ obszarze bezpieczeństwa wewnętrznego", 21-22 October 2015, Wólka Nadbużańska, Poland.

Wasiluk, A. 2013. Zaufanie i współpraca pomiędzy przedsiębiorstwami $w$ perspektywie budowy i rozwoju struktur klastrowych, Ekonomia $i$ Zarzqdzanie 4: 49-66.

Wasiluk, A.; Daniluk, A. 2013. The possibilities of creating cross - border clusters. Vilnius: Vilnius University Publishing House. 